\title{
Teachers views about the preparation of questions for question bank on the basis of subject content for the formative assessment of the department.
}

\section{Tasnim S, Saria T, KK Alam, A.B.M R Rhaman \& R Kibria}

\begin{abstract}
This descriptive type of cross-sectional study was conducted to find out the teachers views about the preparation of questions for question bank on the basis of subject content for the formative assessment of the department. The study was conducted in four government and four non-government dental colleges. The teachers of the selected dental colleges were the study population and sample size was total of a 165 in which were 53 head of the department and 112 lecturers. Data was collected from the teachers with a self-administered semi-structured questionnaire and analyzed by using SPSS 19. The questionnaire included different types of opinion about the question bank. In this study, tried to extract the information mainly about how a full phased question bank works in a dental college including question pattern and answer key preparation, moderation \& constant development of the question bank, key personnel who directly involved with question preparation. Faculty members expressed their valuable opinions about different types of formative questions where it was found that Assistant Professors were closely involved with question preparation rather than other faculty members. The study also explores that even if formative questions were well prepared but lack of standard answers, rating scales and accepted checklist made the ultimate process of accessing question bank becomes challenging to conduct specific exams.
\end{abstract}

\section{Key Word: Preparation of questions, Question bank, Formative assessment}

1. Dr. Sanjida Tasnim, BDS, MMEd, Dental surgeon

2. Professor Dr Saria Tasnim, Head of the Department (OBGYN), Dhaka Community Medical College \& Hospital

3. Dr. Kazi Khairul Alam, Associate Professor, Curriculum Development \& Evaluation, CME

4. Dr. ABM Rizwanur Rahman, Assistant Professor \& Head, Dept. of Oral Pathology \& Periodontology, Dhaka Community Medical College \& Hospital

5. Dr. Raihan Kibria, Lecturer, Dept. of Orthodontics, Marks Medical College Hospital \& Dental Unit

Address of correspondence: Dr. Sanjida Tasnim, BDS, MMEd, Dental surgeon, email: drstasnim@gmail.com

\section{Introduction}

A question bank is a planned library of test items designed to fulfill certain predetermined purposes. Question bank should be prepared with utmost care so as to cover the entire prescribed text. Question bank should be exhaustive and cover entire content with different types. We can consider three different level for developing a question bank, teachers own question bank, departmental question bank and central question bank (Basavanthappa, B.T. 2003). Question bank contain all questions systematically including their standard answers, rating scales, difficulty level, discrimination properties and test matrix of a course. Question banking is considered as a part of the examination reform. This question bank helps universities to maintain standard of education at same level in all colleges. 
Teacher should have essential efforts in preparing good questions and their standard answers and rating scales. So, it is preferable and economical to maintain a question bank for all types of good questions. It was a great source of readymade quality questions where teachers and examiners have easy access. It improves the overall quality of a test because only good (valid and reliable) questions are retained in the question bank and these are reused (Qureshi, F., 2009).

Questioning is the most important device of teaching. The teacher-learning process becomes effectives, when knowledge is given and shares in the class; through this questioning. The teacher can know the amount of knowledge acquired by the students with the help of questioning (Khan, Z., 2016). The questions should be prepared in clear and simple language, it means that the words in a question should be clear and simple, suited to the ability of the students. The coordinators ask for questions from relevant lecturers, giving information regarding subject area/discipline, type of question whether multiple choice questions (MCQ), short answer questions (SAQ), objective structured clinical/practical (OSPE or OSCE) and number of questions for each subject area and type of questions.

The present study mainly focus on to find out means of preparing questions and its extent of use the dental institutes and the role of the faculty members to develop the question bank.

\section{Methodology}

This descriptive type of cross sectional study was conducted among four Government and four non-Government dental colleges and units. Sample size was total of 165 teachers among where 53 head of the departments and 112 Lecturers were included in this study. Teachers of department who was present and willing to provide information regarding study during the period of data collection. Data were collected by semi structured questionnaire. All the data were checked, edited to reduce errors and organized manually. The collected data were duly entered, processed and analyzed in SPSS 19 version. All of the data were presented in the form of tables and graphs. All faculty members/teachers was selected on voluntary basis. This study conducted after getting permission from all respective authorities. Information and identity of the respondent were anonymous and confidentiality of the data were maintained.

\section{Results}

The study was descriptive type of cross sectional study. The result of this study has been set the opinions of teachers according to the objectives.

Table 1 Distribution of teachers by their Age and Gender

\begin{tabular}{|l|l|c|l|l|c|}
\hline \multicolumn{3}{|c|}{ Head of the department (n=53) } & \multicolumn{3}{|c|}{ Lecturer (n=112) } \\
\hline \multirow{2}{*}{ Age group } & \multicolumn{2}{|c|}{ Gender } & Age group & \multicolumn{2}{c|}{ Gender } \\
\cline { 2 - 3 } & $\begin{array}{l}\text { Male } \\
\boldsymbol{f ( \% )}\end{array}$ & $\begin{array}{c}\text { Female } \\
\boldsymbol{f ( \% )}\end{array}$ & & $\begin{array}{l}\text { Male } \\
\boldsymbol{f}(\%)\end{array}$ & $\begin{array}{l}\text { Female } \\
\boldsymbol{f ( \% )}\end{array}$ \\
\hline $34-39$ & $12(22.6)$ & $13(24.5)$ & $25-30$ years & $19(17.0)$ & $29(25.9)$ \\
\hline $40-45$ & $18(34.0)$ & $7(13.2)$ & $31-35$ years & $28(25.0)$ & $23(20.5)$ \\
\hline $46-51$ & $2(3.8)$ & - & $36-40$ years & $6(5.4)$ & $5(4.5)$ \\
\hline $52-59$ & - & $1(1.9)$ & $41-45$ years & $2(1.8)$ & - \\
\hline
\end{tabular}

Bangladesh Journal of Medical Education 2021; 12(2); Tasnim et al., publisher and licensee Association for Medical Education Bangladesh. This is an Open Access article which permits unrestricted noncommercial use, provided the original work is properly cited. 
Table 1 shows that among the respondents' there were 53 departmental heads and 112 lectures. The respondent majorities were male among the head of the department $60.4 \%$ and majorities were female among the lecturers $50.9 \%$. Majorities of the head of the department $94.3 \%$ were from 34 to 45 age group and $93.4 \%$ lecturers were from 25 to 35 age group.

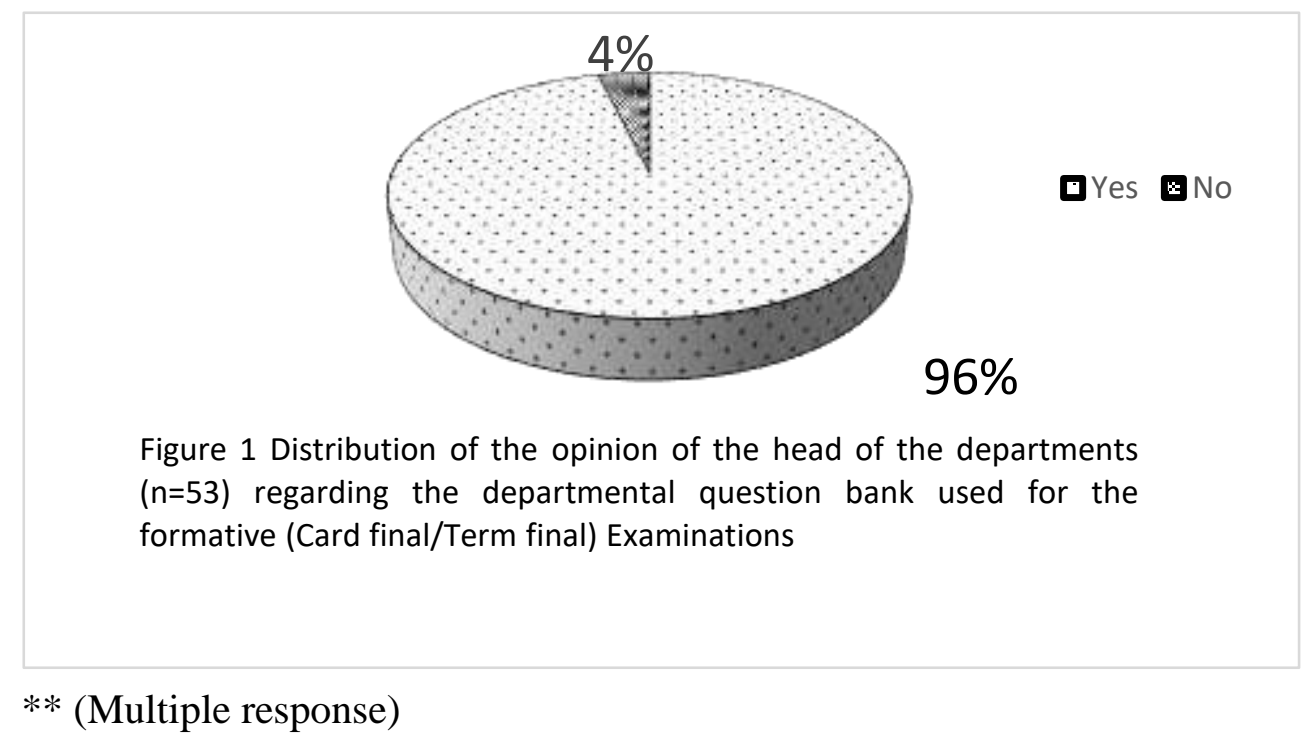

Table 2 Distribution of the opinion of the head of the department $(n=53)$ regarding the faculty members involvement in preparing Short Answer Questions (SAQ), Multiple Choice Questions (MCQ), Structure Oral Examination (SOE) and Objective Structure Clinical/Practical (OSCE/OSPE) Questions in card final/ward final, term final examinations

\begin{tabular}{|c|c|c|c|c|c|}
\hline Preparing the questions & $\begin{array}{l}\text { Professor } \\
f(\%)\end{array}$ & $\begin{array}{l}\text { Associate } \\
\text { Professor } \\
\boldsymbol{f}(\%)\end{array}$ & $\begin{array}{l}\text { Assistant } \\
\text { Professor } \\
\boldsymbol{f}(\%)\end{array}$ & $\begin{array}{l}\text { Lecturer } \\
f(\%)\end{array}$ & $\begin{array}{l}\text { Registrar } \\
f(\%)\end{array}$ \\
\hline SAQ in card /ward examination & $12(22.6)$ & $15(28.3)$ & $43(81.1)$ & $33(62.3)$ & $9(17)$ \\
\hline SAQ in term examination & $13(24.5)$ & $18(34)$ & $46(86.8)$ & $27(50.9)$ & $9(17)$ \\
\hline MCQ in card /ward examination & $11(20.8)$ & $12(22.6)$ & $32(60.4)$ & $37(69.8)$ & $9(17)$ \\
\hline MCQ in term examination & $13(24.5)$ & $16(30.2)$ & $47(88.7)$ & $25(47.2)$ & $9(17)$ \\
\hline SOE in card/ward examinations & $9(17)$ & $14(26.4)$ & $38(71.7)$ & $31(58.5)$ & $9(17)$ \\
\hline SOE in term examinations & $14(26.4)$ & $24(45.3)$ & $48(90.6)$ & $22(41.5)$ & $9(17)$ \\
\hline OSCE/OSPE in card/ward & $10(18.9)$ & $8(15.1)$ & $36(67.9)$ & $30(56.6)$ & $9(17)$ \\
\hline examinations & $14(26.4)$ & $12(22.6)$ & $45(84.9)$ & $26(49.1)$ & $9(17)$ \\
\hline OSCE/OSPE in term examir & & & & & \\
\hline
\end{tabular}

Bangladesh Journal of Medical Education 2021; 12(2); Tasnim et al., publisher and licensee Association for Medical Education Bangladesh. This is an Open Access article which permits unrestricted noncommercial use, provided the original work is properly cited. 
Table 2 displays opinion of the head of the departments, faculty members' involved in preparing questions. Highest ratio was $86.8 \%$ and $88.7 \%$ assistant professor involved prepared the SAQ and MCQ questions in term final examinations and highest ratio was $90.6 \%$ and $84.9 \%$ assistant professor involved prepared the SOE and OSCE/OSPE questions in term final examinations.

\begin{tabular}{|c|c|c|c|c|}
\hline $\begin{array}{l}\text { Answer are prepared in different types of } \\
\text { question }\end{array}$ & Never $f(\%)$ & $\begin{array}{l}\text { Rare } \\
f(\%)\end{array}$ & $\begin{array}{l}\text { Sometimes } \\
f(\%)\end{array}$ & $\begin{array}{l}\text { Always } \\
f(\%)\end{array}$ \\
\hline $\begin{array}{l}\text { Prepare standard answers for the SAQs } \\
(n=53)\end{array}$ & $6(11.3)$ & $6(11.3)$ & $17(32.1)$ & $24(45.3)$ \\
\hline Prepare the rating scale of the SAQs $(n=52)$ & $8(15.4)$ & $7(13.5)$ & $19(36.5)$ & $18(34.6)$ \\
\hline $\begin{array}{l}\text { Prepare the answer keys of the MCQs } \\
(n=52)\end{array}$ & - & - & $8(15.4)$ & $44(84.6)$ \\
\hline $\begin{array}{l}\text { Prepare the agreed/standard answers of the } \\
\text { SOEs }(n=53)\end{array}$ & $8(15.1)$ & $8(15.1)$ & $19(35.8)$ & $18(34.0)$ \\
\hline $\begin{array}{l}\text { Prepare the checklist/rating scale of the } \\
\text { OSCE/OSPEs }(n=53)\end{array}$ & $3(5.7)$ & $3(5.7)$ & $14(26.4)$ & $33(62.3)$ \\
\hline
\end{tabular}

Table 3 illustrates that preparing standard/agreed answers, answer keys, rating scale/checklist in different type of questions. Majority head of the departments $84.6 \%$ said that 'Always' prepare the answer key of the MCQs and $34.6 \%$ head of the departments agreed that the rating scale of the SAQs \& agreed/standard answers of the SOEs are lesser prepared than MCQs.

\section{Table 4 Distribution of the opinion of the lecturer regarding the preparation of standard answers/agreed answers, answer keys, checklist and rating scales in different types of questions}

\section{Prepare different types of answer}

Prepare standard answers and rating scales for SAQ questions $(\mathrm{n}=112)$

Prepare answer keys for MCQ questions ( $\mathrm{n}=111)$

Prepare agreed/standard answers for SOE questions $(\mathrm{n}=111)$

Prepare checklist for objective structure clinical/practical examination (OSCE/OSPE) questions $(\mathrm{n}=112)$

$\begin{array}{ccc}\text { Yes } & \text { No } & \text { Other } \\ f(\%) & f(\%) & (f \%)\end{array}$

$\begin{array}{lll}59(52.7) & 44(39.3) & 9(8) \\ 95(85.6) & 14(12.6) & 2(1.8) \\ 66(59.5) & 38(34.2) & 7(6.3) \\ 70(62.5) & 40(35.7) & 2(1.8)\end{array}$

Bangladesh Journal of Medical Education 2021; 12(2); Tasnim et al., publisher and licensee Association for Medical Education Bangladesh. This is an Open Access article which permits unrestricted noncommercial use, provided the original work is properly cited. 
Prepare answer first before constructing a questions $(\mathrm{n}=111)$

Prepare the questions just before/after the class $(n=103)$

Prepare the questions covering the contents $(n=111)$

Cross check all the questions, answers and rating scales by other teachers $(n=111)$

Maintain separate files for written, oral and practical questions $(n=110)$

$\begin{array}{lll}82(73.9) & 26(23.4) & 3(2.7) \\ 51(45.5) & 49(43.8) & 3(2.7) \\ 98(88.3) & 7(6.3) & 6(5.4) \\ 60(54.1) & 37(33.3) & 14(12.6) \\ 91(81.3) & 12(12.5) & 7(6.3)\end{array}$

questions covering the contents is more $88.3 \%$ and less Prepare the questions just before/after the class is $45.5 \%$.
Table 4 shows that more prepare answer keys for MCQ questions $85.6 \%$ and less prepare the standard answers and rating scales for SAQ questions $52.7 \%$ and

Table 5 Distribution of the opinion of the head of the department $(n=53)$ regarding the proportion of different types of Short Answer Question (SAQ), Structure Oral Examination (SOE) and Objective Structure Clinical/Practical Examination (OSCE/OSPE) question in their subject

\section{Types of the questions}

Question are recall type in SAQ

$(\mathrm{n}=51)$

Question are understanding type in

SAQ $(\mathrm{n}=52)$

Question are problem solving type in

SAQ $(n=50)$

Question are recall type in SOE

$(\mathrm{n}=50)$

Question are understanding type in

SOE $(n=51)$

Question are problem solving type in

SOE $(n=46)$

Assess procedural skills in

OSCE/OSPE $(\mathrm{n}=47$ )

Assess communication skill in

OSCE/OSPE $(n=46)$

Assess application skills in

OSCE/OSPE $(n=44)$

Proportion of the questions

$\begin{array}{rrrr}\mathbf{0 - 2 5 \%} & \mathbf{2 6 - 5 0 \%} & \mathbf{5 1 - 7 5 \%} & \mathbf{7 6 - 1 0 0 \%} \\ 10(19.6) & 29(56.8) & 10(19.6) & 2(4.0) \\ 8(15.3) & 38(73.1) & 5(9.6) & 1(1.9) \\ 30(60.0) & 20(40.0) & - & - \\ 8(16.0) & 32(64) & 8(16.0) & 2(4.0) \\ 10(19.7) & 30(58.8) & 7(13.8) & 4(7.8) \\ 34(74.0) & 12(26.1) & - & - \\ 7(14.9) & 26(55.3) & 12(25.6) & 2(4.3) \\ 35(76.0) & 11(23.9) & - & - \\ 31(68.8) & 8(15.5) & 4(13.4) & 1(2.2)\end{array}$

Bangladesh Journal of Medical Education 2021; 12(2); Tasnim et al., publisher and licensee Association for Medical Education Bangladesh. This is an Open Access article which permits unrestricted noncommercial use, provided the original work is properly cited. 
Table 5 shows that proportion of the questions were understanding type in SAQ was $73.1 \%$ group of $26-50 \%$ and problem solving type questions were lowest as its $60 \%$ group of $0-25 \%$. Most of the question were recall type in SOE 64\% group of 26$50 \%$ and problem solving type questions were lowest as its $74 \%$ group of $0-25 \%$. In practical assessment, most of the questions were to assess procedural skills was $55.3 \%$ group of $26-50 \%$ and assess communication skill were lowest was $76 \%$ group of $0-25 \%$.

\section{Discussion}

The total of 53 head of the department and 112 lecturer were participated in the different stages of this study. The respondent majorities were male among the head of the department $60.4 \%$ and majorities were female among the lecturers $50.9 \%$. Majorities of the head of the department $94.3 \%$ were from 34 to 45 age group and $93.4 \%$ lecturers were from 25 to 35 age group. It's a vital question whether any formative question bank (Card final/Term final) were in place or not in the department and used for the formative examination where majority participants gave their positive feedback and the related percentage were $96.2 \%$.

In this study discuss about four different pattern of questions prepared for card final and term final examinations. It was observed that opinion of the head of the departments, faculty members' involved in preparing questions in different types of exam. Highest ratio was $86.8 \%$ and $88.7 \%$ assistant professor involved prepared the SAQ and MCQ questions in term final examinations. Second highest ratio was more than $60 \%$ lecturers prepared the questions in card final examinations and lowest ratio was more than $30 \%$ professor and associate professor involved prepare questions in term final examinations. The highest ratio was $90.6 \%$ and $84.9 \%$ assistant professor involved prepared the SOE and OSCE/OSPE questions in term final examinations.

In this study found that head of the department agreed with $84.6 \%$ answer keys were prepared for the multiple choice questions, prepare standard answers for the short answer questions $45 \%$, prepare the agreed/standard answers of the structure oral examination (SOE) questions was $34 \%$ which were stored in the archive whereas rating scale/checklist for the OSCE/OSPE questions for the separate exams which percentage is $62.3 \%$.

Equally the lecturers' said that in this study more prepare answer keys for MCQ questions $85.6 \%$ and less prepare the standard answers and rating scales for SAQ questions $52.7 \%$ and questions covering the contents is more $88.3 \%$ and less Prepare the questions just before/after the class is $45.5 \%$.

In the study of Alam KK(2008) found that difficulties arise during constructing 'SAQ answer keys' 23\%, constructing 'MCQ answer key' 23\%, constructing 'SOE answer key' 20\%, constructing OSCE/OSPE stations $22 \%$ and difficult to complete syllabus within course periods $16 \%$.

Question pattern differs according to the pattern of exams. There were three type of formative questions such as recall, understanding and problem solving type. proportion of the questions were understanding type in SAQ was $73.1 \%$ group of 26-50\% and problem solving type questions were lowest as its $60 \%$ group of $0-25 \%$. Most of the question were recall type in SOE $64 \%$ group of $26-50 \%$ and problem solving type questions were lowest Bangladesh Journal of Medical Education 2021; 12(2); Tasnim et al., publisher and licensee Association for Medical Education Bangladesh. This is an Open Access article which permits unrestricted noncommercial use, provided the original work is properly cited. 
as its $74 \%$ group of $0-25 \%$. In practical assessment, most of the questions were to assess procedural skills was $55.3 \%$ group of $26-50 \%$ and assess communication skill were lowest was $76 \%$ group of $0-25 \%$.

The study of Manara A \& Uddin MN (2012) found that recall and understanding type question in SAQ $85.64 \%$ and $14.36 \%$ in written test of Bangladesh University of Professionals and $84.33 \%$ and $15.67 \%$ in written tests of Dhaka university respectively in MBBS course.

In the study of Alam KK(2008) also found that different domains were covered in different formative written examinations. It was observed that $70 \%$ written questions are 'recall' type; $20 \%$ questions are 'understanding type'; $10 \%$ written questions were 'application type'. It was also observed that $70 \%$ or less of their viva questions of the formative test were 'recall type'; $20 \%$ of their viva questions of the formative test were 'understanding type'; $40 \%$ OSCE/OSPE questions measure motor skills and 20\% OSCE/OSPE questions measure communication skills whereas about $60 \%$ and $57 \%$ teachers of the para clinical and clinical subjects claimed this respectively.

\section{Conclusion}

Question paper and its evaluation have been and will remain a fundamental part of education to class the students with their performance towards learning and to meet the requirements of the goals and objectives of the medical and dental council. Question paper preparer and people who involved in the whole process generally fulfill their tasks with great integrity. Although it's a very complicated scenario to discuss with and numerous pattern of questions are involved with their appropriate answer sheet, checklist and rating scale but still with the expertise and dedication of our respected faculty members this is also possible.

\section{References}

1. Alam, K.K. (2008); Formative assessment in undergraduate medical education in medical colleges of Bangladesh: Situation analysis (thesis); Centre for Medical education: Dhaka, page no:67,69-71.

2. Basavanthappa, B.T., (2003); "Text book of nursing education" 1 st edition, Newdelhi jaypee brothers publications, page no: 473-476, 537539.

3. Khan, Z., (2016); Questioning is an important device, http://www.Yourarticlelibary.com.edu

4. Manara, A., Uddin,M.N., Habib,M.A., Ayub,M.(2012); Reflection of SAQ in undergraduate anatomy MBBS course according to new curriculum of BMDC, JAFMC Bangladesh. Vol 8, No 2, page no:3-6.

5. Qureshi, F.,(2009); Question bank, Sayadwad Institute of Higher Education and Research https:// www. slideshare. net/mobi 